\title{
IAMJ
}

INTERNATIONAL AYURVEDIC MEDICAL JOURNAL

\section{A CONCEPTUAL STUDY OF AMA DESCRIBED IN AYURVEDA}

\section{Priyanka Kaushik}

M.D. (Rog Nidan Evum Vikriti Vigyan)

Assistant Professor, Bharti Ayurveda Medical College and Hospital, Durg, (C.G.), India

Corresponding Author: priyanka0139@gmail.com

\section{https://doi.org/10.46607/iamj04p5032021}

(Published online: March 2021)

Open Access

(C) International Ayurvedic Medical Journal, India 2021

Article Received: 21/02/2021 - Peer Reviewed: 13/03/2021 - Accepted for Publication: 15/03/2021

\section{Check for updates}

\begin{abstract}
Ayurveda is an ancient science of life. It has its own basic concepts like Dosha, Dhatu, Mala, Agni etc. Ama is also one of them. It plays a major role in Dhatu (Dosha, Dhatu, Mala) Vaishmya (vitiation) and production of various diseases in the body. According to Ayurveda Mandagni (hypofunctioning of digestive fire) is the basic cause of all diseases. Ama is considered as Apakwa Ahara Rasa (unripe, undigested or partially digested food) which is produced due to Mandagni. Further it circulates all over the body through Srotas (channel of circulation) causes Srotovaigunya (vitiation in channel of circulation) and plays a major role in manifestation of various diseases. Dosha, Dhatu and mala vitiated by Ama are known as Sama Dosha, Sama Dushya and Sama Mala. If the treatment principle of disease is planned by understanding the concept of Sama and Niram, it would give a better result. In this review article the concept of Ama is described from different Ayurvedic Smahitas and texts.
\end{abstract}

Keywords: Concept of Ama, Sama, Niram, Agni.

\section{INTRODUCTION}

'Ama' is one of the most important basic concepts described in Ayurveda. It is helpful to understand the disease pathology and determining its line of treatment. According to Ayurveda the root cause of all disease is Mandagni (hypofunction of Agni). ${ }^{1}$ Due to hypo functioning of Agni proper digestion of food doesn't takes place leading to formation of Ama, which is responsible for the manifestation of almost all diseases. ${ }^{2}$ In all diseases there is the stages of Dosha and Dushya Vaishmya (vitiation). For better treatment it is 
important to understand that the Dushit (vitiated) Dosha or Dushya is either Sama or Niram. So, in this article the concept of Ama, its production at different levels and its detailed overview in all Samhitas has been described.

\section{Aim and Objectives:}

To study the concept of Ama and its importance to decide the line of treatment.

\section{Materials and methods:}

Ayurvedic Samhitas and textual materials have been used for this study various references have been collected. Modern texts, related websites and related articles have also been searched.

\section{Conceptual study:}

\section{Definition of Ama:}

- Due to the hypo-functioning of the Ushma (Agni), the first Dhatu i.e. the Rasa is not properly formed. Instead the Annarasa (taken food) undergoes Dustatva (fermentation or putrefaction) being retained in the Amashaya (small intestine). It is the state of Rasa which is called $\mathrm{Ama}^{3}$

- If Kayagni (digestive fire of the body) fails to perform normal functions leads to accumulation of undigested food material inside Amashaya, which is the initial Rasadhatu is called $\mathrm{Ama}^{4}$

- Food, which is improperly digested having foul smell, excess unctuousness and develops lethargy in all body organs is called $\mathrm{Ama}^{4}$

- Due to hypo-functioning of Agni proper digestion of food doesn't takes place leading to formation of $A m a$, which is responsible for the manifestation of almost all diseases. ${ }^{4}$

- Some people accept Ama as improperly digested food. ${ }^{4}$

- Some others consider accumulated Mala (excretory products) as $\mathrm{Ama}^{4}$

- Due to Nidan Sevan (having etiological factors) Agni is vitiated and is unable to digest even less amount of food and this undigested food after getting fermented turns to poisonous substance. ${ }^{5}$

Analysis of above definitions yields that Ama is a stage of premature Paka (digestion) before attaining its final Paka and this Ama can be formed at any level of Agni i.e. Jatharagni, Bhutagni and Dhatvagni.

\section{Ama Nidana (Etiological factors of Ama):}

Mandagni is the main cause of Ama. The Nidanas (etiological factors) which cause Agnimandya (hypofunction of Agni) may produce Ama. In Ayurvedic texts the causative factors of $A m a$ are described in various places which can be classified in following manner.

\section{Aharaja Nidana (Dietetic factors):} Agni is deranged by Abhojana (fasting), Ajirna Bhojana (eating during indigestion). Atibhojana (overeating), Vishambhojana (irregular eating), Asatmya Bhojana (intake of unsuitable), Guru (heavy), Sheet (cold), Atiruksha (too rough), Sandushta Bhojana (contaminated food). ${ }^{6}$

Ahara Parinamkara Bhava plays active role on the food digestion process, Like Ushna digests, Vayu absorbs, Kleda produces looseness, Sneha generate softness, Kala brings it to complete transformation and $\mathrm{Sa}$ mayoga means the use and need of the Ashta Aharavidhi, Ritu (season), Desha (place) etc. Samayoga is interpreted as balance use of 8 factors regarding diet. Imbalance state of Ahara Parinamkar Bahva causes Agni Vikruti (vitiation of Agni) which is the main cause of Amotpatti (production of Ama). ${ }^{7,8}$

\section{Viharaja Nidana (Behavioral factors):}

Mithya Vihara means lifestyle, which is unfavorable, unwanted and inconvenient to the body resulting into imbalance of Doshas.

- Atyambupan (more intake of water)

- Vishamashana (irregular dietary habits)

- Vegadharana (suppression of vomiting and other natural Vegas)

- Swapnaviparyaya (day sleep after lunch and latenight sleep or night awakening)

\section{Manasika Nidanas (Psychological factors):}

Mental condition also plays big role in the production of Ama. Such factors have been mentioned by Acharya Charaka in Vimanasthana.

Even the wholesome food also taken in proper quantity, does not get digested due to Chinta (anxiety), Shoka (grief), Bhaya (fear), Krodh (anger), Dukhashayyaprajagarana (uncomfortable bed).

\section{Others:}

- Improper administration of Vamana, Virechana and Snehana. 
- Vyadhi Karshana - wasting of the tissue which results due to prolonged illness.

- Desha-Kala-Ritu Vaishamya - allergic states or change in place climate.

\begin{tabular}{|l|l|l|l|}
\hline Aharaja Nidana & Viharaja Nidana & Manasik Nidana & Anya \\
\hline Abhojana & Viruddha cheshta & Kama & Emaciation due to chronic disease \\
\hline Atibhojana & Nishchaltava & Krodha & Adverse season habitat and time \\
\hline Adhyashana & Diwaswapna & Lobha & \\
\hline Vishamashana & Ratrijagarana & Moha & \\
\hline Viruddhashana & Vega-Vidharana & Irshya & \\
\hline & Ativyayama & Bhaya & \\
\hline & Ativyawaya & Shoka & \\
\hline & Snigdh Bhojanottara Vyayama & Chinta & \\
\hline & Vishamashayya Shayan & Deenata & \\
\hline & & & \\
\hline & &
\end{tabular}

\section{Pathogenesis of Ama:}

The food which is not digested properly in Amashaya exhibits four stages as follows.

1) Apakva Ahara Rasa - food which is not digested properly and gives rise to Ajeernadi diseases.

2) Ama/Ama rasa-Apakva Ahara Rasa in Amashaya undergoes Shuktatva (fermentation) after some time that is called as Ama or Ama Rasa.

3) Ama Dosha - this Ama later on becomes pathogenic due to interaction with Doshas and is called as Ama Dosha. ${ }^{12}$
- Vegadharana means suppression of natural Vegas like bowel habit, micturition, tears, sleep etc. resulting into the vitiation of Vata Dosha which can further cause vitiation of Agni and Tridosha prakopa.
Ama Visha - on further stasis, this Ama Dosha becomes more and more toxic that attains the qualities of Visha (poison) is called as Amavisha.

The Dushita (vitiated) Vatadi Doshas, being mixed up with one another, lead to the formation of Ama Dosha, very much like the yielding of Visha (toxic or poisonous substance) by the spoiled Kodrava. ${ }^{13}$

Thus, Doshas which are vitiated by this Ama and Dushya (Dhatus) which are further vitiated by these Doshas are known as Sama (Sama Dosha or Sama Dhatu). Diseases caused by the involvement of these Samas are known as Sama Vyadhi. ${ }^{14}$

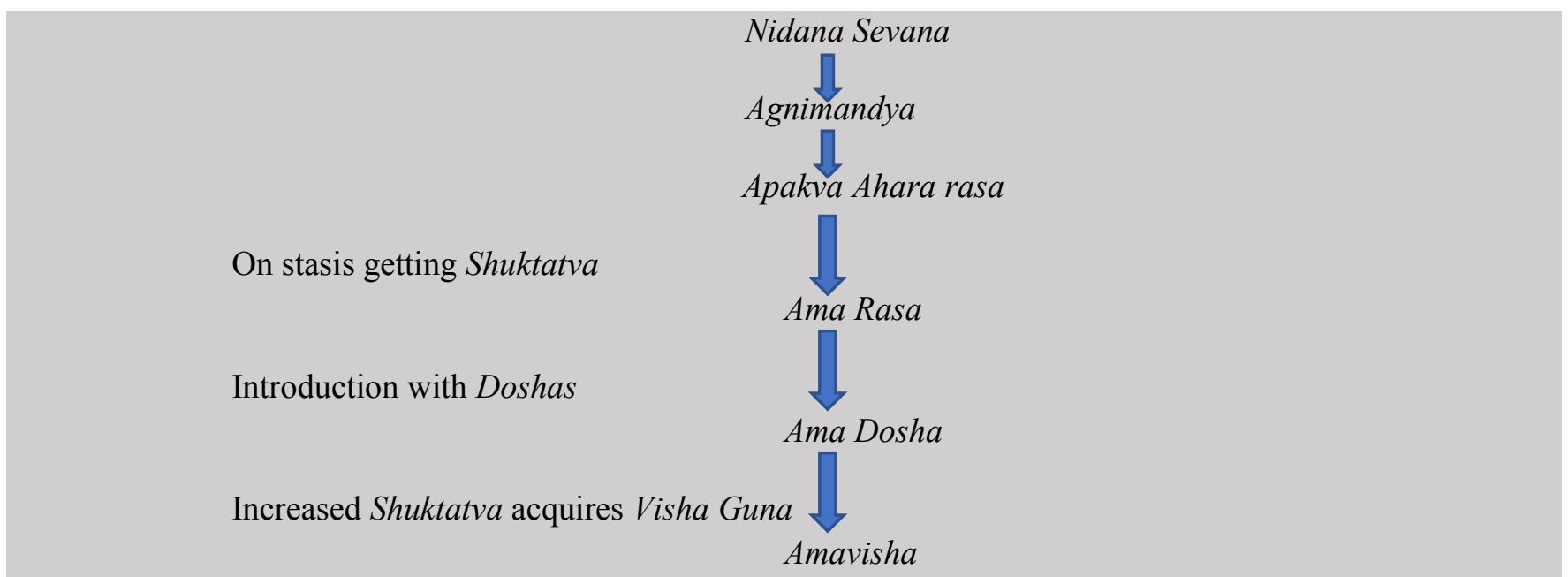




\section{General symptoms of $\mathbf{A m a}:{ }^{15}$}

1. Srotorodha (obstruction in Srotas); 2. Balabhransa (diminution of strength); 3. Gaurava (feeling of heaviness); 4. Anil Mudhata (disturbance in the normal movement of Vata); 5. Alasya (laziness); 6. Apaka (indigestion); 7. Nisthivana (excessive secretion from oral cavity); 8. Malasanga (obstruction for urine and stool); 9. Aruchi (lack of desire towards food); 10. Klama (exhaustion)

Symptoms of Sama and Nirama Dosha: The Doshas mixed with Ama are referred as 'Sama Doshas' which in turn vitiates the Dushyas like Rasa, Rakta, Mamsa, Meda etc.

Sama Vata Dosha Lakshana : ${ }^{16,17}$

1. Vibandha (constipation); 2. Agni Sada (decreased appetite); 3. Tandra (Drowsiness); 4. Antrakujan (gurgling in intestine); 5. Vedana (pain); 6. Shotha (edema); 7. Toda (pricking in organs); 8. Snehadai Vruddhim Aayati Meghe Suryodaye Nishi (features increase on oleation, during clouds in the sky, during morning, during evening)

2. Vatjan Gadan (gives rise to other Vataj disorders) Nirama Vata Dosha Lakshana : ${ }^{18}$

1. Vishado (clear); 2. Ruksho (dry); 3. Nirgandho (non-smelling); 4. Alpa Vedana (produces little pain); 5. Snigdhaihi Shanti (alleviates on application of oil); 6. Viparit Gunaihi Shanti (alleviates on administration of opposite properties)

Sama Pitta Dosha Lakshana: ${ }^{19,20}$

1. Amla (sour/ acidic); 2. Durgandham (bad smelling); 3. Haritam (greenish); 4. Shyavam (Blackish); 5. Guru (heavy); 6. Sthiram (Stable); 7. Amlapittakar (gives rise to GERD); 8. Kantha Hrit Dahakar (gives rise to burning in chest); 9. Trishnakar (increases thrist); 10. Mukhamayan (may give rise to other oral diseases); 11. May give rise to other Pitta Rogas.

\section{Nirama Pitta Dosha Lakshana: ${ }^{21}$}

1. Tamram (copper coloured); 2. Ati Ushnam (hot); 3. Katukam (bitter); 4. Saram (spready); 5. Ugragandhi (foul smelling); 6. Ruchi Krit (arouses test); 7. Vanhi Bala Vardhan (increases appetite)

Sama Kapha Dosha Lakshana: ${ }^{22,23}$

1. Avil (increased cloudiness); 2 Tantul (with fibrils);

3. Styan (increased stickiness); 4. Durgandha (bad smelling); 5. Trit Upaghatakrit (suppresses thirst); 6. Kshudha Upaghatalrit (suppresses appetite); 7. Yakshma kar (may give rise to disease Rajyakshma); 8 . Mehakar (may give rise to disease Prameha); 9. Pinas kar (may give rise to disease rhinitis); 10. May give rise to other Pitta Rogas.

Nirama Kapha Dosha Lakshana: ${ }^{24}$

1. Nirgandha (odourless); 2. Fenwan (bubbling); 3. Chhedwan (can be separated in lumps); 4. Pindita (from a lump when spitted); 5. Pandu (whitish yellowish); 6. Aasyavairasya Nashkrit (arouses test in mouth) Sama Dushya: The Dhatus mixed with Ama are referred as 'Sama Dushya'. When Annavisha is mixed with Rasadi Dhatus it produces various diseases of those Dhatus. ${ }^{25}$

Sama Mala: The Malas mixed with Ama are referred as 'Sama Mala'. When Annavisha enters the urinary bladder and is combined with urine, it causes disorders of the urine and when it is mixed with Mala (faeces), it causes many disorders of the abdomen. ${ }^{26}$

The Sama Vit (undigested stool) sinks in water due to heaviness whereas the properly digested stool floats on water. $^{27}$

\section{DISCUSSION}

Ama is one of the most important fundamental concepts of Ayurveda to understand the pathophysiology of diseases. According to all Acharyas Ama is the root cause of many diseases, which forms due to the hypo functioning of Agni. Due to Jatharagnimandya, Ahara Rasa is not digested properly which forms Apakva Ahara Rasa i.e. Ama. Apakva Ahara Rasa in Amashaya undergoes Shuktatva after some time and that is called as Ama or Ama Rasa. This Ama later on becomes pathogenic due to interaction with Doshas it is called as Ama Dosha. Further this Ama Dosha become more and more toxic that attains the quality of Visha is called as Ama Visha.

After analyzing the following facts become clear about Ama.

1) Mandagni is the root cause of production of Ama but the Agni is not specified by most of the Acharyas. So, it is quite clear that anywhere in the body 
if Agni is not working properly the Ama will be produced.

2) Ama is produced from Ahara rasa when it is not properly digested in case of Jathargnimandya but in case of other Agnis undigested or partially digested metabolites may be Ama.

3) Place of origin of Ama is given as Amashaya. But considering the Agni at different levels Ama can be produced at different levels at different sites in the body.

4) All Acharyas were having same opinion that Ama is the root causes of many diseases.

In various diseases the main cause is imbalance of Doshas. The general symptoms of Ama are helpful to determine that the vitiated Doshas are Sama or Nirama.

\section{CONCLUSION}

The formation of Ama occurs due to vitiated function of Agni. In normal state the Agni is responsible for Bala (strength), Arogya (health), Ayu (longevity) and Prana (vitality). But in the other side when its function disturbs it produces Ama and become the cause of various disorders because "Roga Sarve Api Mandagni." So, Agni should be protected by proper dietary habits and other lifestyles described in Ayurveda. In this article the causative factors i.e. Nidana are described which are responsible for Amotpatti. Avoidance of these Nidanas is the primary step to stop the production of Ama by Nidan Pariwarjana. Ultimately this will be in the greater interest of the society which is also called social welfare.

In Ayurveda the cause of any disease is imbalance one or more than one Doshas. To decide the right line of treatment it is necessary to determine, weather the imbalanced Dosha is Saam or Niram. By understanding this stage and deciding the line of treatment and drug as per Dosha Avastha the treatment will be more successful. So, it will be helpful for the Vaidyas to give more fruitful results.

\section{REFERENCES}

1. Dr. Brahmanand Tripathi; Ashtanga Hridaya, Delhi, Chaukhamba Sanskrit Pratisthana; 2009 (Nidansthana Chapter 12/1) Page No. 512
2. Prof. Yadundana Upadhyay: Madhava Nidana; The Madhukosha Sanskrit Commentary, Varanasi, Part 1 Chaukhambha Prakashana: 2013 (Chapter 25/1-5) Page No. 509

3. Dr. Bulusu Sitaram; Astanga Hridaya, Varanasi, Chaukhambha Orientalia. 2008 (Sutrasthan Chapter 13/25) Page No. 176

4. Prof. Yadundana Upadhyay: Madhava Nidana; The Madhukosha Sanskrit Commentary, Varanasi, Part 1 Chaukhambha Prakashana: 2013 (Chapter 25/1-5) Page No. 509

5. Prof. Priyavrat Sharma; Charak Samhita Vol 2 (Chikitsa Sthan Chapter 15/44); Varanasi; Chaukhambha Orientalia; 2005; Page No. 253

6. Prof. Priyavrat Sharma; Charak Samhita Vol 2 (Chikitsa Sthan Chapter 15/42); Varanasi; Chaukhambha Orientalia; 2005; Page No. 253

7. Prof. Priyavrat Sharma; Charak Samhita Vol 1 (Sharir Sthan Chapter 6/14); Varanasi; Chaukhambha Orientalia; 2005; Page No. 449

8. Prof. Priyavrat Sharma; Charak Samhita Vol 1 (Vimana Sthan Chapter 1/21); Varanasi; Chaukhambha Orientalia; 2005; Page No. 305

9. G. D. Singhal; Sushruta Samhita; Part 1 (Sutrasthan 46/500) Delhi, Chaukhambha Pratisthana; 2007, Page No. 490

10. Prof. Priyavrat Sharma; Charak Samhita Vol 1 (Vimana Sthan Chapter 2/9); Varanasi; Chaukhambha Orientalia; 2005; Page No. 311

11. Prof. Priyavrat Sharma; Charak Samhita Vol 2 (Chikitsa Sthan Chapter 15/42); Varanasi; Chaukhambha Orientalia; 2005; Page No. 253

12. Prof. Priyavrat Sharma; Charak Samhita Vol 2 (Chikitsa Sthan Chapter 15/44-49); Varanasi; Chaukhambha Orientalia; 2005; Page No. 253

13. Dr. Bulusu Sitaram; Astanga Hridaya, Vol. 1 (Sutrasthan Chapter 8/26) Varanasi, Chaukhambha Orientalia. 2008page No. 176

14. Dr. Bulusu Sitaram; Astanga Hridaya, Vol. 1 (Sutrasthan Chapter 8/27) Varanasi, Chaukhambha Orientalia. 2008page No. 176

15. Dr. Brahmanand Tripathi; Ashtanga Hridaya, (Sutrasthana Chapter 13/23-24) Delhi, Chaukhamba Sanskrit Pratisthana; 2012 Page No. 188

16. Pt. Brahmashankar Mishra; Bhavaprakash Samhita (Madhyam Khanda Jwar Chikitsa 63-64); Varanasi; Chaukhambha Orientalia; Page No. 504

17. Pt. Kashinath Shastri, Dr. Gorakhanath Chaturvedi; Charak Samhita Vol 2 (Chikitsa Sthan Chapter15/48); 
Varanasi; Chaukhambha Bharti Academy; 2012; Page No. 460

18. Pt. Brahmashankar Mishra; Bhavaprakash Samhita (Madhyam Khanda Jwar Chikitsa 65); Varanasi; Chaukhambha Orientalia; Page No. 504

19. Pt. Brahmashankar Mishra; Bhavaprakash Samhita (Madhyam Khanda Jwar Chikitsa 66); Varanasi; Chaukhambha Orientalia; Page No. 505

20. Pt. Kashinath Shastri, Dr. Gorakhanath Chaturvedi; Charak Samhita Vol 2 (Chikitsa Sthan Chapter15/47); Varanasi; Chaukhambha Bharti Academy; 2012; Page No. 460

21. Pt. Brahmashankar Mishra; Bhavaprakash Samhita (Madhyam Khanda Jwar Chikitsa 67); Varanasi; Chaukhambha Orientalia; Page No. 505

22. Pt. Brahmashankar Mishra; Bhavaprakash Samhita (Madhyam Khanda Jwar Chikitsa 68); Varanasi; Chaukhambha Orientalia; Page No. 505

23. Pt. Kashinath Shastri, Dr. Gorakhanath Chaturvedi; Charak Samhita Vol 2 (Chikitsa Sthan Chapter15/47); Varanasi; Chaukhambha Bharti Academy; 2012; Page No. 460

24. Pt. Brahmashankar Mishra; Bhavaprakash Samhita (Madhyam Khanda Jwar Chikitsa 69); Varanasi; Chaukhambha Orientalia; Page No. 505

25. Pt. Kashinath Shastri, Dr. Gorakhanath Chaturvedi; Charak Samhita Vol 2 (Chikitsa Sthan Chapter15/49); Varanasi; Chaukhambha Bharti Academy; 2012; Page No. 460

26. Pt. Kashinath Shastri, Dr. Gorakhanath Chaturvedi; Charak Samhita Vol 2 (Chikitsa Sthan Chapter15/49); Varanasi; Chaukhambha Bharti Academy; 2012; Page No. 460

27. Pt. Kashinath Shastri, Dr. Gorakhanath Chaturvedi; Charak Samhita Vol 2 (Chikitsa Sthan Chapter15/94); Varanasi; Chaukhambha Bharti Academy; 2012; Page No. 466.

\section{Source of Support: Nil Conflict of Interest: None Declared}

How to cite this URL: Priyanka Kaushik: A Conceptual Study Of Ama Described In Ayurveda. International Ayurvedic Medical Journal \{online\} 2021 \{cited March, 2021\} Available from:

http://www.iamj.in/posts/images/upload/2787_2792.pdf 